\title{
Antioxidant enzyme cycling over reproductive lunar cycles in Pocillopora damicornis
}

\author{
James WA Murphy ${ }^{\text {Corresp., } 1,2}$, Abby C Collier ${ }^{3}$, Robert H Richmond ${ }^{1}$ \\ ${ }^{1}$ Kewalo Marine Laboratory, Pacific Biosciences Research Center, University of Hawaii at Manoa, Honolulu, Hawaii, United States \\ 2 Department of Molecular Biosciences and Bioengineering, University of Hawaii at Manoa, Honolulu, Hawaii (HI), United States \\ 3 Faculty of Pharmaceutical Sciences, University of British Columbia, Vancouver, British Columbia, Canada \\ Corresponding Author: James WA Murphy \\ Email address: jwmurphy@hawaii.edu
}

The impacts of continued degradation of watersheds on coastal coral reefs world-wide is alarming, and action addressing anthropogenic stressors and subsequent rehabilitation of watersheds and adjacent reefs is an urgent priority. The aim of this study is to develop and improve the use of antioxidant enzymes as bioindicators of stress in coral species. In order to fully develop such tools, it is necessary to first understand baseline cycling of these enzymes within coral tissues. Due to inherent links between reproduction and oxidative stress, these aims may be facilitated by sampling coral tissues over reproductively-linked lunar cycles to determine variations from baseline. By developing a greater understanding of biochemical markers of stress in corals, specifically antioxidant defense enzymes catalase (CAT), glutathione reductase (GR), glutathione peroxidase (GPx), and superoxide dismutase (SOD) in Hawaiian Pocillopora damicornis, we have provided molecular tools that identify thresholds of stress on coral reefs. Our results suggest that the coral reproductive state is a significant factor affecting the activity of antioxidant enzymes. Specifically, CAT and GR display maximum activity during peak reproductive state. Whereas significant maximal Se-independent GPX and SOD activity was measured during off-peak reproductive cycles. Such insight into the cyclical variation of the activity of these enzymes should be applied towards differentiating the influence of natural biological activity cycling in diagnostic tests identifying the effects of different physical environmental factors and chemical pollutants on coral health. Through the development and application of these molecular biomarkers of stress, we look to improve our ability to identify problems at the sub-lethal level, when action can be taken to mitigate a/biotic impacts. 
1 Antioxidant Enzyme Cycling over Reproductive Lunar Cycles in Pocillopora damicornis

2

3 Murphy, JWA ${ }^{\mathbf{1}, \mathbf{2}}$; Collier, $\mathrm{AC}^{\mathbf{3}}$; and Richmond, $\mathbf{R H}^{\mathbf{1}}$

41 Kewalo Marine Laboratory, Pacific Biosciences Research Center, University of Hawai ' $\mathrm{i}$ at

5 Mānoa, Honolulu, HI, United States, 96813, 2 Department of Molecular Biosciences and

6 Bioengineering, University of Hawai'i at Mānoa, Honolulu, HI, United States, 96822, 3 Faculty

7 of Pharmaceutical Sciences, University of British Columbia, Vancouver, BC, Canada, V6T1Z3

8

9 Corresponding Author:

10 James WA Murphy

1141 Ahui Street, Honolulu, HI, 96813, USA

12 Email Address: jwmurphy@hawaii.edu 


\section{Abstract}

15 The impacts of continued degradation of watersheds on coastal coral reefs world-wide are alarming, and action addressing anthropogenic stressors and subsequent rehabilitation of

17 watersheds and adjacent reefs is an urgent priority. The aim of this study is to develop and 18 improve the use of antioxidant enzymes as bioindicators of stress in coral species. In order to fully develop such tools, it is necessary to first understand baseline cycling of these enzymes within coral tissues. Due to inherent links between reproduction and oxidative stress, these aims may be facilitated by sampling coral tissues over reproductively-linked lunar cycles to determine variations from baseline. By developing a greater understanding of biochemical markers of stress in corals, specifically antioxidant defense enzymes catalase (CAT), glutathione reductase (GR), glutathione peroxidase (GPx), and superoxide dismutase (SOD) in Hawaiian Pocillopora damicornis, we have provided molecular tools that identify thresholds of stress on coral reefs.

Our results suggest that the coral reproductive state is a significant factor affecting the activity of antioxidant enzymes. Specifically, CAT and GR display maximum activity during peak reproductive state. Whereas significant maximal Se-independent GPx and SOD activity was measured during off-peak reproductive cycles. Such insight into the cyclical variation of the activity of these enzymes should be applied towards differentiating the influence of natural biological activity cycling in diagnostic tests identifying the effects of different physical environmental factors and chemical pollutants on coral health. Through the development and application of these molecular biomarkers of stress, we look to improve our ability to identify problems at the sub-lethal level, when action can be taken to mitigate a/biotic impacts. 


\section{Introduction}

Corals are critical to the structural and biological integrity and function of coral reef ecosystems (Birkeland, 1997). Because anthropogenic stress is increasingly impacting global marine environmental health (Gattuso et al., 2015; Heron et al., 2016; Hughes et al., 2017; Maynard et al., 2015), it is vital that techniques for evaluating coral stress [prior to reef collapse] are developed and applied (Edge et al., 2013). Recent advances in the application of molecular analyses to facilitate sub-lethal stress evaluations in corals have been substantial (Ainsworth et al., 2008; Barshis et al., 2014; Desalvo et al., 2008; Downs et al., 2012; Edge et al., 2013; Rougée et al., 2006). Researchers concerned with coral health, stress, bleaching events and their total effects on the state of reef health, need to develop new and better diagnostic tools that address coral stress prior to death and that can inform policy, improve conservation efforts, and assist in saving coral reefs as a legacy for the future.

One way that this can be accomplished is by developing tests for the evaluation of specific stress responses. Antioxidant stress enzymes, for example, are useful for the analysis of stressor impacts on the health of coral animals due to their involvement in physiological responses to a variety of stressors (Downs et al., 2006; Higuchi et al., 2015; Vijayavel et al., 2012). Antioxidant enzyme presence and activity in coral tissues have the potential to be employed as metrics for evaluating stress on reefs, including gradients of stress, and pin-pointing the impacts toxicants on the health of corals (Edge et al., 2013; Rivest \& Hofmann, 2014). Such molecular biomarkers can determine the degree of stress affecting specific areas of the reef or the gradient over which a pollutant source may be diffusing across a reef (Downs et al., 2006). A library of biomarkers will be valuable in identifying physiological stress prior to coral death.

Previous studies have highlighted antioxidant enzymes as useful biomarkers of the impacts of stressors such as heat, xenobiotic exposure, and high-irradiance (Downs et al., 2006; Higuchi et al., 2015; Liñán-Cabello et al., 2010; Olsen et al., 2013). However, as useful as this suite of enzymes is in providing information about coral stress responses and threat levels, many of the substrates that trigger this type of stress are naturally produced in normal homeostatic processes (Agarwal et al., 2006; Dowling \& Simmons, 2009; Fujii et al., 2005). Adding these biomarkers to the available tools that can be employed to evaluate reef health is important and requires knowledge of baseline levels of protein expression and activity, including measurements over reproductive cycles. In order to have full confidence in using these enzymes as biomarkers 
67 for stress detection, it is important to take into consideration how endogenous levels of activity 68 may change over shifting baselines. As such, prior to expanding our use of these enzymes as diagnostic tools for oxidative stress responses, we seek to characterize whether reproductive cycling has a discernable effect on the enzymatic profile of a widely distributed species of coral, Pocillopora damicornis.

This study of coral reproduction in relation to baseline shifts in enzyme activity arose in part from publications describing cyclical variation in the activity of xenobiotic metabolizing enzymes during reproduction events. A study performed by Rougée et al. (2014) illustrated variations in the expression and activity of xenobiotic metabolizing enzymes during reproductive cycling in the coral P. damicornis. Glucuronosyltransferase, glutathione-s-transferase (GST), cytochrome P450 2E1, and cytochrome P450 reductase were all found to fluctuate significantly over natural reproductive lunar cycles (Rougée et al., 2014). Additionally, research by Ramos et al. (2011) provided insight into the effect of reproductive cycling on various biotransformation and antioxidant enzyme activities. In their work, activities of cytochromes P450, GST, NADPH $\mathrm{c}$ reductase, and catalase (CAT) were all significantly higher during reproductive peaks in the coral Siderastrea siderea (Ramos et al., 2011). With such evidence for the fluctuation of enzymatic activity tied to reproductive cycling, coupled with the knowledge of reactive oxygen species (ROS) impacts on the health of reproductive systems in non-cnidarian species, the lack of more comprehensive research into antioxidant enzyme expression over reproductive cycles in corals underlines a lack of data regarding antioxidant enzyme expression (Agarwal et al., 2006).

Reproduction is an innate source of ROS generation and relies heavily upon the interplay of pro-oxidants and antioxidants (Agarwal et al., 2006; Fujii et al., 2005; Halliwell \& Gutteridge, 2015; Rahal et al., 2014). This interplay of ROS production and detoxification during reproduction has a critical role in both aiding and inhibiting high quality gamete production, fertilization, and embryo development (Fujii et al., 2005). Studies in non-Cnidarians have pointed to a heightened prevalence of ROS impacting fertility, as well as being implicated in the termination of embryos and reproductive senescence during heightened levels of oxidative stress (Agarwal et al., 2005; Agarwal et al., 2006; Carbone et al., 2003). Oxidative stress also has the potential to reduce embryo growth and decrease fertilization rates (Agarwal et al., 2006). However, ROS are also both beneficial and detrimental to the motility and viability of sperm cells. Specifically, sulfoxidation is required for the maturation of sperm and packaging of nuclei 
in sperm heads, while excess ROS proliferation acting upon the axoneme of spermatozoa can inhibit motility (de Lamirande \& Gagnon, 1992; Fujii et al., 2005). Rich in polyunsaturated fatty acids, spermatozoa are highly vulnerable to lipid peroxidation due to low availability of ROSscavenging enzymes (Agarwal et al., 2006; Saleh \& Agarwal, 2002). As a result, unregulated lipid peroxidation can lead to the production of spermicidal compounds, such as (E)-4-Hydroxy2-nonenal, which at concentrations of only $50 \mu \mathrm{m}$, can result in irreversible motility loss (Selley et al., 1991). Antioxidant compounds, such as glutathione, and ROS-scavenging enzymes, such as superoxide dismutase (SOD), aid in modulating the effects of ROS on egg and sperm viability and promote embryo integrity (Agarwal et al., 2006). Although corals may have different reproductive methods than vertebrates, other invertebrates, and plants, there are commonalities with respect to ROS generation and detoxification that are highly conserved across taxa and are required for optimizing reproductive integrity (Dowling \& Simmons, 2009). To improve the breadth and quality of the biomarkers available, this project sought to define basal enzymatic activity levels in a major coral species with broad global distribution, with respect to reproductive cycling (Hoeksema et al., 2014).

Consistent with the aim of this study to characterize antioxidant enzyme activity over reproductive cycling in corals, colonies of Hawaiian $P$. damicornis (type-B) were chosen for study due to their documented monthly brooding cycles exhibiting peak planula output closely tied to the first-quarter moon phase (Kolinski and Cox, 2003; Richmond \& Jokiel, 1984;

Schmidt-Roach et al., 2012; Stimson, 1978). Characteristic monthly reproductive cycling of $P$. damicornis in Hawaii and the Pacific Islands, suggests this coral as an optimal candidate for study in comparison to other common reef-building corals, such as Porites spp., Acropora spp., and Montipora spp., that seasonally spawn over annual cycles (Harrison et al., 1984; Harrison \& Wallace, 1990; Neves, 2000; Padilla-Gamiño \& Gates, 2012; Stimson, 1978). As such, potential reproductive shifts in antioxidant enzyme activity may be observed over monthly cycles, rather than over an annual reproductive cycle. This also makes the species an excellent candidate for differentiating seasonal variations and year-to-year changes in basal antioxidant enzyme activity variation (Cooper et al., 2009; Harrison \& Wallace, 1990; Ward, 1995). By improving baseline knowledge of endogenous cycles in cellular physiology of major reef-building corals through testing the hypothesis that reproductively-tied lunar cycling has an effect on antioxidant enzyme activity, future studies examining coral health can better identify stress endured by corals with 
129 respect to extreme environmental and anthropogenically-influenced phenomena from natural 130 metabolic enzyme activity cycling.

131

132 Methods

\section{Sample collection}

Coral samples ( $5 \mathrm{~cm}$ x $2.5 \mathrm{~cm}$ nubbins) were collected periodically from the same

135

136

137

138

139

140

141

142

143

144

145

146

147

148

149

150

151

152

153

154

155

156

157

158

159 colonies under Department of Land and Natural Resources - Division of Aquatic Resources coral collection permit SAP 2015-6/17 off Lilipuna Pier, Kāne‘ohe, O‘ahu, Hawai‘i (Fig 1), adjacent to the Hawai'i Institute of Marine Biology (HIMB).

To reduce the impact of fragmentation on the reproductive cycling or output of $P$. damicornis (Zakai et al., 2000), colonies were not fragmented prior to the start of collections. Instead, fragments of branches were sampled from several areas on each colony and included tissue extending from central to distal areas of each branch to ensure reduction of microhabitat influence and intracolony stress load variation between samples. This was also done to limit variations in reproduction potential along coral branches, as polyps found mid-branch retain the highest planula larvae output versus distal and central branch polyps (Harrison \& Wallace, 1990). Sampling was also conducted during falling tides to both reduce residence time in lowflow water and match peak planula release, as it has been correlated with low tide periods (Harrison \& Wallace, 1990). Colonies with minimal competition from other corals and no visible signs of disease or stress were sampled during each moon phase (New, 1/4, Full, 3/4 moon; n=6 colonies) during July and August. Collections also included an acute sampling period, during which corals were sampled daily for five consecutive days following the start of the peak reproductive period moon phase $(1 / 4$ moon) in the month of August. This sampling period was constructed to provide finer resolution for understanding changes in antioxidant enzyme profiles following a reproductive peak.

Fragments were immediately frozen in liquid nitrogen, transported to Kewalo Marine Laboratory (KML) on dry ice, and transferred to a $-80^{\circ} \mathrm{C}$ freezer to preserve enzyme profiles and protein integrity. Prior to protein extraction, corals were crushed into a fine powder using liquid nitrogen and an arbor press.

\section{S9 protein fraction extraction and protein quantification}


Following modified protocols by Lesser et al. (1990), coral S9 post-mitochondrial protein

161 fractions were isolated from crushed coral tissue. Using $1500 \mathrm{mg}$ of crushed tissue and $1500 \mu \mathrm{L}$

162 of homogenization buffer per sample extraction in $50 \mathrm{~mL}$ tubes $(0.01 \mathrm{M}$ Tris-HCl buffer $\mathrm{pH} 8.0$,

$1631 \mathrm{M}$ phenylmethylsulfonyl fluoride in $1 \% \mathrm{v} / \mathrm{v}$ dimethyl sulfoxide), tissue was homogenized for 1

164 minute on ice using an Ultra-Turrax homogenizer. The homogenate was then spun for 5 minutes

165 at $4^{\circ} \mathrm{C}$ at $2000 \mathrm{rcf}$ in an Eppendorf Microcentrifuge 5415D (Hauppauge, NY, USA) to separate

166 skeleton and tissue, and the supernatant was transferred to $1.5 \mathrm{~mL}$ microcentrifuge tubes and

167 spun for 20 minutes at $4^{\circ} \mathrm{C}$ at $10,000 \mathrm{rcf}$. The supernatant was then aliquoted into $1.5 \mathrm{~mL}$ tubes

168 and frozen at $-80^{\circ} \mathrm{C} ; 50 \mu \mathrm{L}$ of each extracted sample was set aside for protein concentration

169 analyses.

170 In preparation for enzymatic activity assays, protein concentrations from each sample

171 were measured using a bicinchoninic acid (BCA) assay. The standard curve was constructed with

172 bovine serum albumin from 0 to $1.0 \mathrm{mg} / \mathrm{mL}$ protein $(25 \mu \mathrm{L} /$ well in triplicate $), 1: 5$ dilutions of

173 aliquots from each extracted S9 sample fraction in double distilled water $\left(\mathrm{ddH}_{2} \mathrm{O}\right)$ were loaded

174 into a 96 well plate in triplicate $(25 \mu \mathrm{L} /$ well). Bicinchoninic acid development reagent $(2 \%$

$175 \mathrm{Cu}^{2+} \mathrm{SO}_{4}$ in BCA; Sigma-Aldrich) was then added into each well (200 $\left.\mu \mathrm{L} / \mathrm{well}\right)$, and the loaded

176 plate was incubated at $37^{\circ} \mathrm{C}$ for 30 minutes. Following incubation, absorbance values were

177 determined at $\lambda=562 \mathrm{~nm}$ in a SpectraMax M5 Micro-Plate spectrophotometer (Molecular

178 Devices, Sunnyvale, CA, USA). To ensure triplicate absorbance variation was within acceptable

179 experimental levels (percent coefficient of variation, $\% \mathrm{CV}<10 \%$; coefficient of determination,

$180 \mathrm{R}^{2}>0.98$ ), data were then exported to Microsoft Excel and \%CV and subsequent standard curve

$181 \mathrm{R}^{2}$ values were calculated. Sample protein concentration values were then interpolated from the

182 standard curve; those extractions falling below $1 \mathrm{mg} / \mathrm{mL}$ required re-extraction of S9 post-

183 mitochondrial protein fractions.

\section{Enzyme activity assays}

Enzyme assays were developed in-house through modifications of protocols for CAT,

GR, GPx, and SOD (Aebi, 1984; Lawrence \& Burk, 1976; McCord \& Fridovich, 1969; Regoli et 
190

191

192

193

194

195

196

197

198

199

200

201

202

203

204

205

206

207

208

209

210

211

212

213

214

215

216

217

218

219

220

Chemical (Ann Arbor, MI, USA). Assays were analyzed using a SpectraMax M5 Multi-Plate reader and final activity values calculated using SoftMax Pro and Microsoft Excel.

The metabolism of $\mathrm{H}_{2} \mathrm{O}_{2}$ as a marker for CAT activity was accomplished by measuring the consumption of $\mathrm{H}_{2} \mathrm{O}_{2}$ over time by analyzing decreasing absorbance of $\mathrm{H}_{2} \mathrm{O}_{2}$ at $\lambda=240 \mathrm{~nm}$. Briefly, the method was performed as follows: on ice, coral protein extractions were first diluted to $1 \mathrm{mg} / \mathrm{mL}$ in $50 \mathrm{mM}$ potassium phosphate buffer $\mathrm{pH} 7.0$ and then loaded, in triplicate (10 $\mu \mathrm{L} /$ well), into optically clear microtiter 96-well plates; negative controls were also run in triplicate containing all assay reagents except $\mathrm{S} 9$ protein to correct for spontaneous $\mathrm{H}_{2} \mathrm{O}_{2}$ degradation during activity reads. Running buffer (50 mM potassium phosphate buffer $\mathrm{pH} 7.0$ ) was then loaded into wells ( $80 \mu \mathrm{L} /$ well), and samples were incubated for 3 minutes at $25^{\circ} \mathrm{C}$. The CAT activity reaction was then initiated by adding $10 \mu \mathrm{L}$ of $120 \mathrm{mM} \mathrm{H}_{2} \mathrm{O}_{2}$ to each well, and immediately transferring the reaction plate into the spectrophotometer to read at 10 second intervals for 5 minutes. In order to dislodge $\mathrm{O}_{2}$ bubbles created by the dismutation of $\mathrm{H}_{2} \mathrm{O}_{2}$ into $\mathrm{H}_{2} \mathrm{O}$ and $\mathrm{O}_{2}$, the spectrophotometer was set to vibrate the 96-well plate between 10 second reads for 2 seconds; this aided in preventing $\mathrm{O}_{2}$ bubbles from obscuring the plate reader's evaluation of $\mathrm{H}_{2} \mathrm{O}_{2}$ absorbance in the reaction wells.

To evaluate the activity of GR, the consumption of NADPH at $\lambda=340 \mathrm{~nm}$ was observed over time as GR in coral samples consumed this co-factor during the reduction of the reagent oxidized glutathione (GSSG). In order to account for both spontaneous degradation of NADPH in reaction wells and endogenous concentrations of NADPH in coral samples, wells containing no coral sample (spontaneous degradation control), and those with coral sample but no NADPH (background level control), were also evaluated alongside wells containing all reagents; in place of coral sample and NADPH, an extra $20 \mu \mathrm{L}$ of $100 \mathrm{mM}$ potassium phosphate buffer (pH 7.2) was added to wells in the first assay step. Values for NADPH degradation obtained from these controls were subtracted from overall activity following assay completion. In optically clear microtiter 96-well plates, $100 \mathrm{mM}$ potassium phosphate buffer was loaded into wells (130 $\mu \mathrm{L} /$ well, in triplicate), followed by $100 \mathrm{mM}$ ethylenediaminetetraacetic acid (EDTA) in $\mathrm{ddH}_{2} \mathrm{O}$ (10 $\mu \mathrm{L} /$ well), $10 \mathrm{mM}$ GSSG in $\mathrm{ddH}_{2} \mathrm{O}(20 \mu \mathrm{L} /$ well $), 1.2 \mathrm{mM} \mathrm{NADPH}$ in $\mathrm{ddH}_{2} \mathrm{O}(20 \mu \mathrm{L} /$ well $)$, and $1 \mathrm{mg} / \mathrm{mL}$ coral sample $(20 \mu \mathrm{L} /$ well $)$. Plates were then loaded into the spectrophotometer and mixed using its mixing function for 5 seconds. Absorbance reads were conducted at 20 second intervals for 5 minutes at $25^{\circ} \mathrm{C}$. 
To evaluate the activity of GPx, assays were broken into two parts in order to determine

222 the activity of both selenium-dependent and selenium-independent forms of this enzyme. As

223

224

225

226

227

228

229

230

231

232

233

234

235

236

237

238

239

240

241

242

243

244

245

246

247

248

249

250

251 such, the loading protocol in place for evaluating the activity of selenium-dependent GPx employed $\mathrm{H}_{2} \mathrm{O}_{2}$ as the initiator and substrate for this reaction, including sodium azide $\left(\mathrm{NaN}_{3}\right)$ to inhibit CAT activity from consuming $\mathrm{H}_{2} \mathrm{O}_{2}$ and interfering with assay results. To evaluate the activity of selenium-independent GPx, cumene hydroperoxide (CHP) was utilized in place of $\mathrm{H}_{2} \mathrm{O}_{2} ; \mathrm{NaN}_{3}$ was not employed as a CAT inhibitor due to the change in substrate, and buffer volumes were adjusted to bring the final reaction volume to $200 \mu \mathrm{L}$. In order to achieve the breakdown of their substrates, GPx use reduced glutathione (GSH) as the cofactor for hydroperoxide reduction, producing oxidized glutathione as the final product (GSSG). In order to visualize this breakdown and quantify GPx activity, this assay has been adapted to measure the consumption of reduced NADPH by GR to replenish GSH from the GPx by-product, GSSG. By this method, measured decreases in NADPH are proportional to GPx activity, which is monitored at $\lambda=340 \mathrm{~nm}$ for 5 minutes at 20 second intervals in optically clear 96-well microtiter plates. Three sets of reference wells were run to account for: degradation of assay substrates over time (no coral sample with substrates), non-specific oxidation of NADPH in this assay (no $\mathrm{H}_{2} \mathrm{O}_{2}$ or CHP), and endogenous levels of substrate in coral tissue samples (coral sample with no substrate). Assay reagents consisted of: $100 \mathrm{mM}$ potassium phosphate buffer ( $\mathrm{pH} 7.0 ; 130,140$, 110 , and $120 \mu \mathrm{L} /$ well for reference, no $\mathrm{H}_{2} \mathrm{O}_{2}$, coral sample, and blank wells, respectively), 20 $\mathrm{mM} \mathrm{NaN}_{3}$ working solution in $\mathrm{ddH}_{2} \mathrm{O}(10 \mu \mathrm{L} /$ well; only for Se-dependent GPx assays $), 100 \mathrm{mM}$ EDTA in $\mathrm{ddH}_{2} \mathrm{O}(10 \mu \mathrm{L} /$ well $), 100 \mathrm{mM}$ GSH working solution in $\mathrm{ddH}_{2} \mathrm{O}(20 \mu \mathrm{L} /$ well $), 100$ $\mathrm{U} / \mathrm{mL}$ GR working solution in $\mathrm{ddH}_{2} \mathrm{O}(10 \mu \mathrm{L} /$ well $), 1 \mathrm{mg} / \mathrm{mL}$ coral samples in $100 \mathrm{mM}$ potassium phosphate buffer ( $\mathrm{pH} 7.0 ; 20 \mu \mathrm{L} /$ well in coral sample and blank wells only), 1.25 $\mathrm{mg} / \mathrm{mL}$ NADPH working solution in $\mathrm{ddH}_{2} \mathrm{O}\left(10 \mu \mathrm{L} /\right.$ well), $150 \mathrm{mM} \mathrm{H}_{2} \mathrm{O}_{2}$ working solution (10 $\mu \mathrm{L} /$ well in reference and coral sample wells only), and $150 \mathrm{mM} \mathrm{CHP}$ working solution (10 $\mu \mathrm{L} /$ well in reference and coral sample wells only; only for Se-independent GPx assays). Upon loading plates into the spectrophotometer, plates were mixed for 5 seconds, and absorbance changes immediately read.

Since SOD catalyzes the dismutation of $\mathrm{O}_{2}{ }^{-}$to $\mathrm{H}_{2} \mathrm{O}_{2}$ and $\mathrm{O}_{2}$, this assay conducted an indirect evaluation of SOD activity by analyzing the degree of inhibition of the reduction of cytochrome $\mathrm{c}$ by $\mathrm{O}_{2}{ }^{-}$. Reagents and samples were loaded into a 96-well microtiter plate in 
252 triplicate, loaded into and mixed using the mixing function in the spectrophotometer for 5

253 seconds, and analyzed for decreasing absorbance $(\lambda=550 \mathrm{~nm})$ for 5 minutes in 20 second

254 intervals at $25^{\circ} \mathrm{C}$. For this assay, wells were loaded in the following order: $100 \mathrm{mM}$ potassium

255 phosphate buffer ( $\mathrm{pH} 7.8,80,74,94 \mu \mathrm{L} /$ well for reference, coral sample, and coral blank wells,

256 respectively), working buffer (100 mM potassium phosphate buffer ( $\mathrm{pH} 7.8), 0.2 \mathrm{mM}$ EDTA in

$257 \mathrm{ddH}_{2} \mathrm{O}, 100 \mu \mathrm{M}$ hypoxanthine in $\mathrm{ddH}_{2} \mathrm{O}$, and $20 \mu \mathrm{M}$ cytochrome $\mathrm{c}$ in $\mathrm{ddH}_{2} \mathrm{O} ; 100 \mu \mathrm{L} /$ well),

258 coral samples diluted to $1 \mathrm{mg} / \mathrm{mL}$ in $100 \mathrm{mM}$ potassium phosphate buffer $(\mathrm{pH} 7.8 ; 6 \mu \mathrm{L} /$ well in

259 coral sample and blank wells only), and reactions were initiated with the addition of $300 \mathrm{mU} / \mathrm{mL}$

260 of $\mathrm{O}_{2}$ - generating xanthine oxidase in $\mathrm{ddH}_{2} \mathrm{O}(20 \mu \mathrm{L} /$ well in reference and coral sample wells

261 only).

262

263

Statistical analyses

264 Statistical data analyses were conducted using Prism 7.03 (GraphPad Software, La Jolla,

265 CA, USA). Data normality was evaluated using the D'Agostino and Pearson Omnibus normality

266 test. Data were then run through one-way analyses of variance (ANOVA) with Tukey's post-hoc

267 test to elucidate significant variances between sample means; $\mathrm{p}<0.05, \alpha=0.05, \mathrm{CI}=95 \%$.

268 Under normal circumstances, repeated measures tests would be suitable for such statistical

269 analysis due to sampling of the same colonies over time. However, several issues with volatility

270 of ROS and products during kinetic assays led to the exclusion of samples where triplicate runs

271 experienced abnormal jumps in enzyme activity. As such, repeated measures tests could not be

272 accomplished, and one-way ANOVAs were instead conducted. Waveform analyses were run to

273 confirm sinusoidal cycling of enzyme activity with respect to moon phase and determine peaks

274 and troughs in enzyme activity under reproductive cycling. Such analyses were conducted

275 utilizing a sine wave analysis fitting data using least squares regression. These were

276 complemented by electing symmetrical, asymptotic confidence intervals $(\mathrm{CI}=95 \%)$ and data

277 goodness-of-fit was visualized through R squared values. These data elucidate biological minima

278 and maxima for enzyme activity, where data below or above such values illustrate suppression or

279 induction of enzyme activity by external factors ("perfect fit" of waveform models was

280 determined by frequency $=1$ ). Residual plots were constructed to confirm error was random.

Results 

cycling over moon phase cycles (Fig 2A). Although significant variations in enzyme activity were only observed between July Full moon and August 1/4 moon sampling periods $(p=0.0044$, $\mathrm{CI}=95 \%)$, CAT activity follows a general sinusoidal trend, with activity peaking during the new and $1 / 4$ moon phases. Resultant information from waveform analyses suggest that baseline reproductive CAT activity is $52.94 \pm 0.23 \mathrm{mmol} / \mathrm{min} / \mathrm{mg}$ protein (amplitude $=12.98 \pm 0.33$ $\mathrm{mmol} / \mathrm{min} / \mathrm{mg}$ protein, frequency $=1.117)$. Peak biological CAT activity is $65.92 \mathrm{mmol} / \mathrm{min} / \mathrm{mg}$ protein, while minimum calculated biological CAT activity fitting this model is 3.99 $\mathrm{mmol} / \mathrm{min} / \mathrm{mg}$ protein. No significant variations in enzyme activity were observed during the

292

293 acute sampling timeline $(\mathrm{p}=0.2374, \mathrm{CI}=95 \%$; Fig 3A). This was expected, however, as there was no significant difference between August $1 / 4$ and full moon collections.

Glutathione reductase activity reflected similar trends as CAT assays, where new and 1/4 moon phases harbored higher enzyme activity than comparative full and $3 / 4$ moon phases (Fig 2B). Activity of GR was significantly higher during July new and $1 / 4$ moon and August $1 / 4$ moon than those values from full and $3 / 4$ moon collection periods $(\mathrm{p}<0.0001, \mathrm{CI}=95 \%)$. Waveform analyses defined baseline biological GR activity as $9.55 \pm 1.02 \mathrm{nmol} / \mathrm{min} / \mathrm{mg}$ protein (amplitude $=3.09 \pm 1.37 \mathrm{nmol} / \mathrm{min} / \mathrm{mg}$ protein). Maximum and minimum biological GR activity were defined as 12.64 and $6.46 \mathrm{nmol} / \mathrm{min} / \mathrm{mg}$ protein, respectively (frequency $=4.83$ ). Glutathione reductase activity was found to significantly decrease from day 1 to day 5 of acute sampling following the August $1 / 4$ moon $(p=0.0189, C I=95 \%$, Fig 3B).

Se-independent GPx activity was found to have significant peaks in activity during both July and August $3 / 4$, and August full moon phases $(p=0.0001, C I=95 \%$, Fig $2 C)$. Inverse to the trends of CAT and GR activity with relation to moon phase cycle, GPx was found to follow a sinusoidal activity curve, with peak activity occurring opposite to $P$. damicornis peak reproductive output. Waveform analysis defined baseline Se-independent GPx activity as $3.28 \pm$ $0.57 \mathrm{nmol} / \mathrm{min} / \mathrm{mg}$ protein (amplitude $2.07 \pm 0.82 \mathrm{nmol} / \mathrm{min} / \mathrm{mg}$ protein). Maximum and minimum biological Se-independent GPx activities were 5.35 and $1.21 \mathrm{nmol} / \mathrm{min} / \mathrm{mg}$ protein (frequency $=1.72$ ). When analyzing values for acute variations in GPx activity following the August $1 / 4$ moon, activity significantly increased in the days following the $1 / 4$ moon phase (Fig 3C). However, only activity of August $1 / 4$ moon day 3 samples were found to be significantly different than other collection time points, having significantly higher activity than those 
314 collected on day 1 of the August $1 / 4$ moon $(p=0.031, C I=95 \%)$. Interestingly, Se-dependent

315 GPx activity was negligible or not detectable across all moon phases and throughout the acute 316 collections ( $p>0.05, \mathrm{CI}=95 \%$, Figs 2D and 3D, respectively). Selenium-dependent GPx did not

317 fit waveform analyses due to multiple zeroes for enzyme activity data.

318 Values for SOD activity, which are inversely proportional to the degree of cytochrome c 319 oxidation over time, showed significantly higher activity during the July full moon cycle versus 320 all other sampling time points $(\mathrm{p}=0.0454-0.0002, \mathrm{CI}=95 \%$, Fig 2E). As such, SOD activity is 321 demonstrated as being highest following the reproductive peak of $P$. damicornis. Data showed 322 good fit for waveform analysis (frequency $=0.91$ ), defining baseline biological SOD activity as $323139.50 \pm 6.23 \mathrm{mmol} / \mathrm{min} / \mathrm{mg}$ protein (amplitude $=15.42 \pm 8.47 \mathrm{mmol} / \mathrm{min} / \mathrm{mg}$ protein).

324 Maximum and minimum biological SOD activity is 154.92 and $124.08 \mathrm{mmol} / \mathrm{min} / \mathrm{mg}$ protein. 325 Acute sampling analysis displayed day 5 of the August $1 / 4$ moon as having significantly higher 326 SOD activity versus days 3 and $4(\mathrm{p}=0.0351$ and $\mathrm{p}=0.0004$, respectively, $\mathrm{CI}=95 \%$, Fig $3 \mathrm{E})$. 327 However, day 5 SOD activity was not significantly different than measured activity from day 1 328 and day $2(\mathrm{p}>0.05, \mathrm{CI}=95 \%)$. What is more, day 2 activity was significantly higher than that 329 calculated during day $4(\mathrm{p}=0.0224, \mathrm{CI}=95 \%)$, suggesting that SOD activity dropped 330 significantly before increasing again between moon phases.

331

\section{Discussion}

In order to develop rapid and efficient tools for detecting sub-lethal levels of stress in corals, first there is a need to define foundational changes in coral protein expression and activity patterns across normal homeostatic processes (Downs et al., 2012; Rougée et al., 2014). Without such definition, there is potential to mistake significant variations in coral health for responses to stress exposure, rather than those due in-part to normal biological processes based on the timing of coral sampling with respect to baseline (Rougée et al., 2006). For example, there would be great importance and versatility in the use of CAT, GR, SOD, and GPx for defining ROSinduced stress in coral animals, which aids in better defining such information as seasonal stress variations, xenobiotic impacts, and thermal stress limitations in corals (Downs \& Downs, 2007; Griffin et al., 2006; Higuchi et al., 2008; Lesser, 1996; Liñán-Cabello et al., 2010). Work to characterize baseline homeostatic levels of activity of these enzymes will benefit the coral conservation biology community and aid in improving experimental design by accounting for 
345 changes in the background activity levels of antioxidant enzymes due to innate biological

346 processes. Further, results from this study help bolster this effort to assess fluctuations in

347 baseline antioxidant enzyme activity levels, as this study found activity values significantly

348 varied in relation to reproductive cycling for CAT, GR, SOD, and GPx. Effectively, this study

349 contributes to reproductive biology as well as conservation and toxicology.

350 Similarly to the findings of Ramos et al. (2011) in S. siderea, a significant peak in CAT

351 activity was observed with relation to peak reproduction in P. damicornis (Fig 2A). Though

352 acute sampling did not detect day-to-day changes in activity values following peak planulation in

353 August (Fig 3A), August 1/4 moon (peak reproductive output) CAT activity was significantly

354 higher than that of July full moon (off-peak reproductive output) activity values ( $p=0.0177, \mathrm{CI}$

$355=95 \%$ ). Waveform analysis data points to well-defined cyclical activity based on the lunar

356 phase, with maximum biological CAT activity occurring during the $1 / 4$ moon cycle. The

357 implications of these findings for CAT activity are in accordance to what has been observed in

358 other coral species and organisms: reproduction is a process during which endogenously

359 generated ROS are produced in P. damicornis. Further, it must be considered that there exist

360 biological minima and maxima for CAT activity $(39.96-65.92 \mathrm{mmol} / \mathrm{min} / \mathrm{mg}$ protein) relevant

361 to the understanding of induction or suppression of this enzyme over a cyclical reproductive

362 scale. Subsequent investigations utilizing CAT activity as a marker for oxidative stress should

363 consider minima and maxima for activity respective to sampling phase.

The finding that significant increases in GR activity are associated with reproductive peaks ( $p=0.0001, C I=95 \%$, Fig $2 B$ ) provides further evidence for the need to consider reproductive time points when using antioxidant enzymes as biomarkers for oxidative stress evaluation. In conjunction with these findings, results illustrating significant decreases in GR activity over the 5-day acute sampling period provide better resolution in identifying the rate at which antioxidant enzyme activities can significantly change over natural $P$. damicornis brooding cycles with activity during day 5 significantly lower than day $1(\mathrm{p}=0.0162, \mathrm{CI}=95 \%$, Fig 3B). Results of GR activity assays provide useful insight into the replenishment of the powerful antioxidant, reduced-glutathione, under reproductive pressures. Similarly to CAT activity measurements, peak and trough data for enzyme activity help demonstrate general trends in naturally cycling GR activity levels in this coral species. These findings suggest that under reproductive peaks, enzymes are utilizing glutathione to reduce ROS to less reactive forms at a 
376

377

378

379

380

381

382

383

384

385

386

387

388

389

390

391

392

393

394

395

396

397

398

399

400

401

402

403

404

405

406

more rapid pace. Such evidence would propose that enzymes, such as GPx would display peaks in activity during reproduction, accordingly. However, this was not observed in sampled colonies.

The enzyme Se-independent GPx displayed significantly greater activity during full and $3 / 4$ moon, rather than new and $1 / 4$ moon phases (Fig 2C). Findings for GPx activity maxima and minima during reproductive peaks and troughs will guide future study design employing Seindependent GPx in P. damicornis stress response detection. However, unlike Se-independent GPx, Se-dependent GPx was not significantly active, as activity assays found little to no detectable activity during the full study period (Figs 2D and 3D). It is possible that associated ROS production during reproductive peaks is not a strong enough driver to elicit synthesis of the Se-dependent form of GPx, or that enzymes, such as CAT, are favored as primary responders to low-levels of ROS within coral tissues. These findings are confounding, as activity patterns inversely mirror those expressed in both CAT and GR. Further, it would be expected that significant increases in GR activity would be proportional to those of GPx enzymes, as the two enzymes work in apposition. However, similar findings illustrating off-peak maxima in the activity of antioxidant enzymes have been documented through the work of Rougée et al. (2014), wherein glutathione-s-transferase, which also utilizes reduced glutathione for pro-oxidant detoxification, and the UDP-glucuronosyltransferase family expressed significantly higher activity 2 weeks following planulation in P. damicornis. Additionally, while GPx-1 is a widely expressed GPx isozyme commonly located within cellular cytosol, mitochondria, and nucleus, it is possible that corals employ different forms of this enzyme for cellular detoxification (Margis et al., 2008). Such variation in the utilization of alternate isozymes has been described in studies of other marine invertebrates, including corals, with respect to their response to hypoxia and anaerobic respiration (Eberlee et al., 1983; Fields, 1983; Fields et al., 1980; Murphy \& Richmond, 2016; Plaxton \& Storey, 1982).

Building upon trends observed for GPx activity, SOD activity was found to experience a small, but significant increase during the July full moon phase versus all other sampling periods with the highest measured inhibition of cytochrome $\mathrm{c}$ reduction $(\mathrm{p}=0.0005, \mathrm{CI}=95 \%$, Fig $2 \mathrm{E})$. Additionally, acute sampling following the August 1/4 moon also found activity to significantly vary, as days 3 and 4 expressed significantly lower activity versus day $5(\mathrm{p}=0.0009, \mathrm{CI}=95 \%$, Fig 3E). This variation highlights potential acute day-to-day shifts in SOD activity unrelated to 
407 reproductive cycling. Supplementary investigations of daily shifts in SOD activity over monthly 408 cycles would help clarifying if detected significant decreases in SOD activity are attributable to

409

410

411

412

413

414

415

416

417

418

419

420

421

422

423

424

425

426

427

428

429

430

431

432

433

434

435

436

437 variations in environmental conditions during sampling or are primarily driven by reproductive peaks. Waveform analyses aided in defining strong cyclical trends in SOD activity with relation to reproductive troughs. Well-defined maximum and minimum values for SOD activity instruct future analysis focused in defining significant changes in coral health in response to external pressures. Additionally, relatively low amplitude in SOD activity cyclicity versus CAT activity suggests that the activity of SOD is more tightly regulated, such that this enzyme may serve a more specialized function during high ROS load versus that of CAT, which may have more diverse biological applications in ROS detoxification. However, like the GPx family of enzymes, SOD harbors a variety of isozymes that contribute to ROS detoxification and may exhibit characteristically different activity during the reproductive cycle leading to these findings. The design of this study sought to isolate $\mathrm{Cu} / \mathrm{Zn} \mathrm{SOD}$ activity through the exclusion of zooxanthellate and mitochondrial tissue fractions, as this isozyme is generally localized within the cytosol of cells (Asada et al., 1977; Fukai \& Ushio-Fukai, 2011). Though Fe and Mn SOD isozymes are generally localized within chloroplasts and mitochondria, respectively, Richier et al. (2003) has described the presence of Fe and Mn SODs within endodermal cnidarian tissues in the anemone Anemonia viridis and Stylophora pistillata (Asada et al., 1977; Fukai \& Ushio-Fukai, 2011). This suggests finer scale improvements should be implemented in future SOD enzyme kinetic assays to isolate activity differences between $\mathrm{Cu} / \mathrm{Zn}, \mathrm{Fe}$, and $\mathrm{Mn}$ SOD from these tissue extraction methods. As such, the utilization of potassium cyanide, an inhibitor of $\mathrm{Cu} / \mathrm{Zn} \mathrm{SOD}$, and $\mathrm{H}_{2} \mathrm{O}_{2}$, an inhibitor of $\mathrm{Fe}$ and $\mathrm{Cu} / \mathrm{Zn} \mathrm{SOD}$, in parallel triplicate wells with the existing SOD assay protocol would allow for the isolation of the activity values for each isozyme, improving the ability to understand how different like-enzymes contribute to ROS detoxification under endogenous ROS cycling (Beauchamp \& Fridovich, 1971; Elstner \& Heupel, 1976; Richier et al., 2003).

These results highlight avenues for continuing studies, as greater investigation into the interplay of ROS generation and detoxification during coral reproduction allude to significant inherent stress thresholds in corals. Now that these data exist, suggesting that coral in the field are undergoing cyclical variations in enzyme activity with relation to reproduction, there is a need to replicate these results in a controlled laboratory setting. This will allow us to control for environmental variables, enhancing data resolution. Although environmental factors were 
438 controlled as much as possible by experimental design (collection times, tides, and sampling 439 around weather anomalies), additional validation of these findings in a controlled laboratory 440 setting would be a natural progression with respect to this research. Expansion of this study 441 through the comparison of antioxidant enzyme activity profiles over different coral species, 442 especially those utilizing broadcast spawning, reproducing on annual scales, and those exhibiting 443 gonochory, would allow us to understand potential interspecies variations and diversity in

444

activity over different reproductive strategies. Furthermore, investigations of antioxidant enzyme activity on the intraspecies level in $P$. damicornis should be conducted across geographic boundaries to elucidate potential location-based differences in activity (Harriott, 1983; Harrison \& Wallace, 1990; Stoddart \& Black, 1985). Finally, though these assays provide valuable insight into coral molecular biology, additional expansion of our capacity to examine coral proteomics, such as the confirmation of protein presence and enzyme isotypes through techniques like HighResolution Mass Spectrometry (such as with a Q-trap), would provide more fine resolution analyses of coral tissue samples and absolute mass determination. This would allow for greater flexibility to diagnose stress biomarkers through enzyme assays, independently confirmed by mass detection of enzyme proteins, that would aid in quantitatively and qualitatively evaluating enzyme variation.

Understanding the influence of reproduction on various biomarker enzymes in coral remains a poorly characterized field that merits expansion. The enzymes employed in this study have been widely applied to evaluate the effect of many abiotic stressors on coral health (FloresRamírez \& Liñán-Cabello, 2007; Higuchi et al., 2008; Liñán-Cabello et al., 2010; Richier et al., 2003; Verma, Mehta, \& Srivastava, 2007; Yakovleva et al., 2004). However, failing to consider reproduction as a source of inherent variation in ROS-induced stress responses presents a potential confounder for studies using these biomarkers by potential mischaracterization of natural fluctuations in antioxidant biomarkers as stress responses. Hence, consideration of reproductive cycling when surveying and comparing coral populations for variability in antioxidant enzyme activity is necessary to prevent confounding data (Agarwal et al., 2005; Agarwal et al., 2006; Fujii et al., 2005; Ramos et al., 2011; Rougée et al., 2014).

\section{Conclusions}


468

469

470

471

472

473

474

475

476

477

478

479

480

481

482

483

484

485

486

487

488

489

490

491

492

493

494

495

The findings of this study illustrate significant changes in the activities of CAT, SOD, GPx, and GR in response to reproductive cycling. These data demonstrate that peaks in the activities of these enzymes correlate with reproductive peaks and troughs over monthly planulation cycles. Due to their value as bioindicators of oxidative stress, our findings demonstrate the importance of determining endogenous cycling of oxidative enzymes tied to reproduction. Such baseline data tied to homeostasis help eliminate confounding factors in studies analyzing the impact of oxidative stress on this species. These results also present greater impetus for future studies elucidating the effects of oxidative stress on reproduction and the overall health of other brooding, and perhaps broadcast spawning, coral species. Molecular tools such as those presented here provide critical data on cause-and-effect relationships between putative stressors and coral health which can be used to guide and evaluate the effectiveness of management and mitigation measures designed to protect coral reefs and those who depend on these magnificent ecosystems.

\section{Acknowledgements}

We would like to thank Narrissa P. Spies for her time and edits that significantly enhanced the quality of this manuscript. We would also like to thank Drs. Paul Jokiel and $\mathrm{Ku}$ 'ulei Rodgers for their assistance in facilitating sample collections and access to the sampling site. Without their support, this research would not have been possible.

Due to the location of this research and cultural ties of the first author, Hawaiian 'oli, or chants, were integrated into the collection protocol. Without a written language, Hawaiians employed 'oli as a means of passing down knowledge in the form of orally communicated genealogies, stories, and protocols for interacting with specific daily or ceremonial practices, among other things. Prior to each collection, "E Hō Mai" and "Nā 'Aumākua" were chanted to ask for knowledge and permission to enter the collection site, while "“Oli Mahalo" was chanted following each collection to both signify the end of the sampling period and give thanks for the coral taken. 
496

497

498

499

500

501

502

503

504

505

506

507

508

509

510

511

512

513

514

515

516

517

518

519

520

521

522

523

524

525

526

527

528

529

530

531

532

533

534

\section{References}

Aebi, H. 1984. Catalase in vitro. Methods in Enzymology 105:121-126 https://doi.org/10.1016/S0076-6879(84)05016-3.

Agarwal A, Gupta S, Sharma RK. 2005. Role of oxidative stress in female reproduction. Reproductive Biology and Endocrinology 3:28 https://doi.org/10.1186/1477-7827-3-28.

Agarwal A, Gupta S, Sikka S. 2006. The role of free radicals and antioxidants in reproduction. Current Opinion in Obstetrics and Gynecology 18:325-332 https://doi.org/10.1097/01.gco.0000193003.58158.4e.

Ainsworth TD, Hoegh-Guldberg O, Heron SF, Skirving WJ, Leggat W. 2008. Early cellular changes are indicators of pre-bleaching thermal stress in the coral host. Journal of Experimental Marine Biology and Ecology 364(2):63-71 https://doi.org/10.1016/j.jembe.2008.06.032.

Asada K, Kanematsu S, Uchida K. 1977. Superoxide dismutases in photosynthetic organisms: absence of the cuprozine enzymein eukaryotic algae. Archives of Biochemistry and Biophysics 179(1):243-256 https://doi.org/10.1016/0003-9861(77)90109-6.

Barshis DJ, Ladner JT, Oliver TA, Palumbi SR. 2014. Lineage-specific transcriptional profiles of Symbiodinium spp. unaltered by heat stress in a coral host. Molecular Biology and Evolution 31(6):1343-1352 https://doi.org/10.1093/molbev/msu107.Beauchamp C \& Fridovich I. 1971. Superoxide dismutase: improved assays and an assay applicable to acrylamide gels. Analytical Biochemistry 44(1):276-287 https://doi.org/10.1016/00032697(71)90370-8.

Birkeland C. 1997. Life and death of coral reefs. Springer Science \& Business Media.

Carbone MC, Tatone C, Delle Monache S, Marci R, Caserta D, Colonna R, Amicarelli F. 2003. Antioxidant enzymatic defences in human follicular fluid: Characterization and agedependent changes. Molecular Human Reproduction 9(11):639-643 https://doi.org/10.1093/molehr/gag090.

Cooper, TF, Gilmour, JP, Fabricius, KE. 2009. Bioindicators of changes in water quality on coral reefs: Review and recommendations for monitoring programmes. Coral Reefs 28(3):589606 https://doi.org/10.1007/s00338-009-0512-x.

de Lamirande E \& Gagnon C. 1992. Reactive oxygen species and human spermatozoa I. effects on motility of intact spermatozoa and on sperm axonemes. Journal of Andrology 13(5):368378 https://doi.org/10.1002/j.1939-4640.1992.tb03327.x.

Desalvo MK, Voolstra CR, Sunagawa S, Schwarz JA, Stillman JH, Coffroth MA, .. Medina M. 2008. Differential gene expression during thermal stress and bleaching in the Caribbean coral Montastraea faveolata. Molecular Ecology 17(17):3952-3971 https://doi.org/10.1111/j.1365-294X.2008.03879.x.

Dowling DK \& Simmons LW. 2009. Reactive oxygen species as universal constraints in lifehistory evolution. Proceedings of the Royal Society B: Biological Sciences 276(1663):1737-1745 https://doi.org/10.1098/rspb.2008.1791. 
535

536

537

538

539

540

541

542

543

544

545

546

547

548

549

550

551

552

553

554

555

556

557

558

559

560

561

562

563

564

565

566

567

568

569

570

571

572

573

574

Downs CA \& Downs A. 2007. Preliminary examination of short-term cellular toxicological responses of the coral Madracis mirabilis to acute Irgarol 1051 exposure. Archives of Environmental Contamination and Toxicology 52(1):47-57 https://doi.org/10.1007/s00244005-0213-6.

Downs CA, Ostrander GK, Rougée LRA, Rongo T, Knutson S, Williams DE, ... Richmond RH. 2012. The use of cellular diagnostics for identifying sub-lethal stress in reef corals. Ecotoxicology 21(3):768-782 https://doi.org/10.1007/s10646-011-0837-4.

Downs CA, Richmond RH, Mendiola WJ, Rougée LRA, Ostrander GK. 2006. Cellular physiological effects of the MV Kyowa violet fuel-oil spill on the hard coral, Porites lobata. Environmental Toxicology and Chemistry / SETAC 25(12):3171-3180 https://doi.org/10.1897/05-509r1.1.

Eberlee JC, Storey JM, Storey KB. 1983. Anaerobiosis, recovery from anoxia, and the role of strombine and alanopine in the oyster Crassostrea virginica. Canadian Journal of Zoology 61(12):2682-2687 https://doi.org/10.1139/z83-353.

Edge SE, Shearer TL, Morgan MB, Snell TW. 2013. Sub-lethal coral stress: Detecting molecular responses of coral populations to environmental conditions over space and time. Aquatic Toxicology 128-129:135-146 https://doi.org/10.1016/j.aquatox.2012.11.014.

Elstner EF \& Heupel A. 1976. Inhibition of nitrite formation from hydroxylammoniumchloride: a simple assay for superoxide dismutase. Analytical Biochemistry 70(2):616-620 https://doi.org/10.1016/0003-2697(76)90488-7.

Fields JHA. 1983. Alternatives to lactic acid: Possible advantages. The Journal of Experimental Zoology: Part A 228(3):445-457 https://doi.org/10.1002/jez.1402280306.

Fields JHA, Eng AK, Ramsden WD, Hochachka PW, Weinstein B. 1980. Alanopine and strombine are novel imino acids produced by a Dehydrogenase found in the adductor muscle of the oyster, Crassostrea gigas. Archives of Biochemistry and Biophysics 201(1):110-114 https://doi.org/10.1016/0003-9861(80)90493-2.

Flores-Ramírez LA \&Liñán-Cabello MA. 2007. Relationships among thermal stress, bleaching and oxidative damage in the hermatypic coral, Pocillopora capitata. Comparative Biochemistry and Physiology - C Toxicology and Pharmacology 146(1-2 SPEC. ISS.):194202 https://doi.org/10.1016/j.cbpc.2006.09.008.

Fujii J, Iuchi Y, Okada F. 2005. Fundamental roles of reactive oxygen species and protective mechanisms in the female reproductive system. Reproductive Biology and Endocrinology 3:43 https://doi.org/10.1186/1477-7827-3-43.

Fukai T \& Ushio-Fukai M. 2011. Superoxide dimutases: role in redox signaling, vascular function, and diseases. Antioxidants and Redox Signaling 15(6):1583-1606 https://doi.org/10.1089/ars.2011.3999.

Gattuso JP, Magnan A, Bille R, Cheung WWL, Howes EL, Joos F, ... Turley C. 2015. Contrasting futures for ocean and society from different anthropogenic $\mathrm{CO} 2$ emissions scenarios. Science 349(6243):aac4722-aac4722 https://doi.org/10.1126/science.aac4722.

Griffin SP, Bhagooli R, Weil E. 2006. Evaluation of thermal acclimation capacity in corals with

Peer] reviewing PDF | (2018:02:24125:2:0:NEW 5 Apr 2019) 
575

576

577

578

579

580

581

582

583

584

585

586

587

588

589

590

591

592

593

594

595

596

597

598

599

600

601

602

603

604

605

606

607

608

609

610

611

612

613

different thermal histories based on catalase concentrations and antioxidant potentials. Comparative Biochemistry and Physiology - A Molecular and Integrative Physiology 144(2):155-162 https://doi.org/10.1016/j.cbpa.2006.02.017.

Halliwell B \& Gutteridge JMC. 2015. Free Radicals in Biology and Medicine (5th ed.). Oxford, United Kingdom: Oxford University Press.

Harriott, VJ. 1983. Reproductive seasonality, settlement, and post-settlement mortality of Pocillopora damicornis (Linnaeus), at Lizard Island, Great Barrier Reef. Coral Reefs 2(3):151-157 https://doi.org/10.1007/BF00336721.

Harrison PL, Babcock RC., Bull GD., Oliver JK., Wallace CC., Willis BL. 1984. Mass spawning in tropical reef corals. Science 223(4641):1186-1189 https://doi.org/ 10.1126/science.223.4641.1186.

Harrison PL \& Wallace CC. 1990. Reproduction, dispersal and recruitment of scleractinian corals. Coral Reefs. Ecosystems of the World (Vol. 25) Elsevier.

Heron SF, Maynard JA, van Hooidonk R, Eakin CM. 2016. Warming trends and bleaching stress of the world's coral reefs 1985-2012. Scientific Reports 6(1):38402 https://doi.org/10.1038/srep38402.

Higuchi T, Fujimura H, Arakaki T, Oomori T. 2008. Activities of antioxidant enzymes (SOD and CAT) in the coral Galaxea fascicularis against increased hydrogen peroxide concentrations in seawater. Proceedings of the 11th Coral Reef Symposium 7-11.

Higuchi T, Yuyama I, Nakamura T. 2015. The combined effects of nitrate with high temperature and high light intensity on coral bleaching and antioxidant enzyme activities. Regional Studies in Marine Science 2:27-31 https://doi.org/10.1016/j.rsma.2015.08.012.

Hoeksema BW, Rodgers A, Quibilan MC. 2014. Pocillopora damicornis. https://dx.doi.org/10.2305/IUCN.UK.2014-1.RLTS.T133222A54216898.en

Hughes TP, Kerry JT, Álvarez-Noriega M, Álvarez-Romero JG, Anderson KD, Baird AH, ... Wilson SK. 2017. Global warming and recurrent mass bleaching of corals. Nature 543(7645):373-377 https://doi.org/10.1038/nature21707.

Kolinski SP \& Cox EF. 2003. An update on modes and timing of gamete and planula release in Hawaiian scleractinian corals with implications for conservation and management. Pacific Science 57(1):17-27 https://doi.org/10.1353/psc.2003.0005.

Lawrence, RA \& Burk, RF. 1976. Glutathione peroxidase activity in selenium-deficient rat liver. Biochemical and Biophysical Research Communications 71(4):952-958 https://doi.org/10.1016/0006-291X(76)90747-6.

Lesser MP. 1996. Elevated temperatures and ultraviolet radiation cause oxidative stress and inhibit photosynthesis in symbiotic dinoflagellates. Limnology and Oceanography 41(2):271-283 https://doi.org/10.4319/1o.1996.41.2.0271.

Lesser MP, Stochaj WR, Tapley DW, Shick JM. 1990. Bleaching in coral reef anthozoans: effects of irradiance, ultraviolet radiation, and temperature on the activities of protective enzymes against active oxygen. Coral Reefs 8(4):225-232 
614

615

616

617

618

619

620

621

622

623

624

625

626

627

628

629

630

631

632

633

634

635

636

637

638

639

640

641

642

643

644

645

646

647

648

649

650

651

652

https://doi.org/10.1007/BF00265015.

Liñán-Cabello MA, Flores-Ramírez LA, Cobo-Díaz JF, Zenteno-Savin T, Olguín-Monroy NO, Olivos-Ortiz A, Tintos-Gómez A. 2010. Response to short term ultraviolet stress in the reefbuilding coral Pocillopora capitata (Anthozoa: Scleractinia). Revista de Biologia Tropical 58(1):103-118 https://doi.org/10.1016/j.cbpa.2008.05.066.

Liñán-Cabello MA, Flores-Ramírez LA, Zenteno-Savin T, Olguín-Monroy NO, Sosa-Avalos R, Patiño-Barragan M, Olivos-Ortiz A. 2010. Seasonal changes of antioxidant and oxidative parameters in the coral Pocillopora capitata on the Pacific coast of Mexico. Marine Ecology 31(3):407-417 https://doi.org/10.1111/j.1439-0485.2009.00349.x.

Margis R, Dunand C, Teixeira FK, Margis-Pinheiro M. 2008. Glutathione peroxidase family An evolutionary overview. FEBS Journal 275(15):3959-3970 https://doi.org/10.1111/j.1742-4658.2008.06542.x.

Maynard J, van Hooidonk R, Eakin CM, Puotinen M, Garren M, Williams G, ... Harvell CD. 2015. Projections of climate conditions that increase coral disease susceptibility and pathogen abundance and virulence. Nature Climate Change 5(7):688-694 https://doi.org/10.1038/nclimate2625.

McCord, JM \& Fridovich, I. 1969. Superoxide dismutase and enzymic function for erythrocuprein (hemocuprein). Journal of Bioloical Chemistry 244(22):6049-6055

Murphy JWA \& Richmond RH. 2016. Changes to coral health and metabolic activity under oxygen deprivation. PeerJ 4:e1956 https://doi.org/10.7717/peerj.1956.

Neves EG. 2000. Histological analysis of reproductive trends of three Porites species from Kane'ohe Bay, Hawai'i. Pacific Science 54(2):195-200 http://hdl.handle.net/10125/1615.

Olsen K, Ritson-Williams R, Ochrietor JD, Paul VJ, Ross C. 2013. Detecting hyperthermal stress in larvae of the hermatypic coral Porites astreoides: The suitability of using biomarkers of oxidative stress versus heat-shock protein transcriptional expression. Marine Biology 160(10):2609-2618 https://doi.org/10.1007/s00227-013-2255-z.

Padilla-Gamiño JL \& Gates RD. 2012. Spawning dynamics in the Hawaiian reef-building coral Montipora capitata. Marine Ecology Progress Series 449:145-160 https://doi.org/10.3354/meps09530.

Plaxton WC \& Storey KB. 1982. Alanopine dehydrogenase: Purification and characterization of the enzyme from Littorina littorea foot muscle. Journal of Comparative Physiology - B 149(1):57-65 https://doi.org/10.1007/BF00735715.

Rahal A, Kumar A, Singh V, Yadav B, Tiwari R, Chakraborty S, Dhama K. 2014. Oxidative stress, prooxidants, and antioxidants : the interplay. BioMed Research International https://doi.org/10.1155/2014/761264.

Ramos R, Bastidas C, Debrot D, García E. 2011. Phase I and II biotransformation and antioxidant enzymes in the coral Siderastrea siderea act as biomarkers for reproductive condition and habitat quality. Marine Biology Research 7(4):398-406 https://doi.org/10.1080/17451000.2010.515684. 
653

654

655

656

657

658

659

660

661

662

663

664

665

666

667

668

669

670

671

672

673

674

675

676

677

678

679

680

681

682

683

684

685

686

687

688

689

690

691

692

Regoli, F, Bocchetti, R, Filho, DW. 2012. Spectrophotometric assays of antioxidants. In: Abele T, Vázquez-Medina JP, Zenteno-Savin T, eds. Oxidative Stress in Aquatic Ecosystems. Blackwell Publishing Ltd, 367-390.

Richier S, Merle PL, Furla P, Pigozzi D, Sola F, Allemand D. 2003. Characterization of superoxide dismutases in anoxia- and hyperoxia-tolerant symbiotic cnidarians. Biochimica et Biophysica Acta - General Subjects 1621(1):84-91 https://doi.org/10.1016/S03044165(03)00049-7.

Richmond RH \& Jokiel PL. 1984. Lunar periodicity in larva release in the reef coral Pocillopora damicornis at Enewetak and Hawaii. Bulletin of Marine Science 34(2):280-287.

Rivest EB \& Hofmann GE. 2014. Responses of the metabolism of the larvae of Pocillopora damicornis to ocean acidification and warming. PLoS ONE 9(4) https://doi.org/10.1371/journal.pone.0096172.

Rougée LRA, Downs CA, Richmond RH, Ostrander GK. 2006. Alteration of normal cellular profiles in the Scleractinian coral (Pocillopora damicornis) following laboratory exposure to fuel oil. Environmental Toxicology and Chemistry / SETAC 25(12):3181-3187 https://doi.org/10.1897/05-510R2.1.

Rougée LRA, Richmond RH, Collier AC. 2014. Natural variations in xenobiotic-metabolizing enzymes: Developing tools for coral monitoring. Coral Reefs 33(2):523-535 https://doi.org/10.1007/s00338-014-1136-3.

Saleh RA \& Agarwal A. 2002. Oxidative stress and male infertility: From research bench to clinical practice. Journal of Andrology 23(6):737-752 https://doi.org/10.1002/j.19394640.2002.tb02324.x.

Schmidt-Roach S, Miller KJ, Woolsey E, Gerlach G, Baird AH. 2012. Broadcast spawning by Pocillopora species on the Great Barrier Reef. PLoS ONE, 7(12): e50847. https://doi.org/10.1371/journal.pone.0050847.

Selley ML, Lacey MJ, Bartlett MR, Copeland CM, Ardlie NG. 1991. Content of significant amounts of a cytotoxic end-product of lipid peroxidation in human semen. Journals of Reproduction and Fertility 92(2):291-298 https://doi.org/10.1530/jrf.0.0920291.

Stimson J. 1978. Mode and timing of reproduction in some common hermatypic corals of Hawaii and Enewetak. Marine Biology 48(2):173-184 https://doi.org/10.1007/BF00395017.

Stoddart, JA \& Black, R. 1985. Cycles of gametogenesis and planulation in the coral Pocillopora damicornis. Marine Ecology Progress Series 23:153-164 https://doi.org/10.3354/meps023153.

Verma RS, Mehta A, Srivastava N. 2007. In vivo chlorpyrifos induced oxidative stress: Attenuation by antioxidant vitamins. Pesticide Biochemistry and Physiology 88(2):191-196 https://doi.org/10.1016/j.pestbp.2006.11.002.

Vijayavel K, Downs CA, Ostrander GK, Richmond RH. 2012. Oxidative DNA damage induced by iron chloride in the larvae of the lace coral Pocillopora damicornis. Comparative Biochemistry and Physiology - C Toxicology and Pharmacology 155(2):275-280 https://doi.org/10.1016/j.cbpc.2011.09.007.

Peer] reviewing PDF | (2018:02:24125:2:0:NEW 5 Apr 2019) 
693 Ward S. 1995. The effect of damage on the growth, reproduction and storage of lipids in the

694

695

696

697

698

699

700

701

702

703 scleractinian coral Pocillopora damicornis (Linnaeus). Journal of Experimental Marine Biology and Ecology 187(2):193-206 https://doi.org/10.1016/0022-0981(94)00180-L.

Yakovleva I, Bhagooli R, Takemura A, Hidaka M. 2004. Differential susceptibility to oxidative stress of two scleractinian corals: Antioxidant functioning of mycosporine-glycine. Comparative Biochemistry and Physiology - B Biochemistry and Molecular Biology 139(4):721-730 https://doi.org/10.1016/j.cbpc.2004.08.016.

Zakai D, Levy O, Chadwick-Furman NE. 2000. Experimental fragmentation reduces sexual reproductive output by the reef-building coral Pocillopora damicornis. Coral Reefs 19(2):185-188 https://doi.org/10.1007/s003380000091. 


\section{Figure 1}

Site map denoting locations of the 6 Pocillopora damicornis colonies of interest in this study.

Sampled colonies were distributed over a $60 \mathrm{~m}$ transect in southern Kāne'ohe Bay, O’ahu, Hawai'i. Photo credit: 2018 Google Earth.

*Note: Auto Gamma Correction was used for the image. This only affects the reviewing manuscript. See original source image if needed for review.

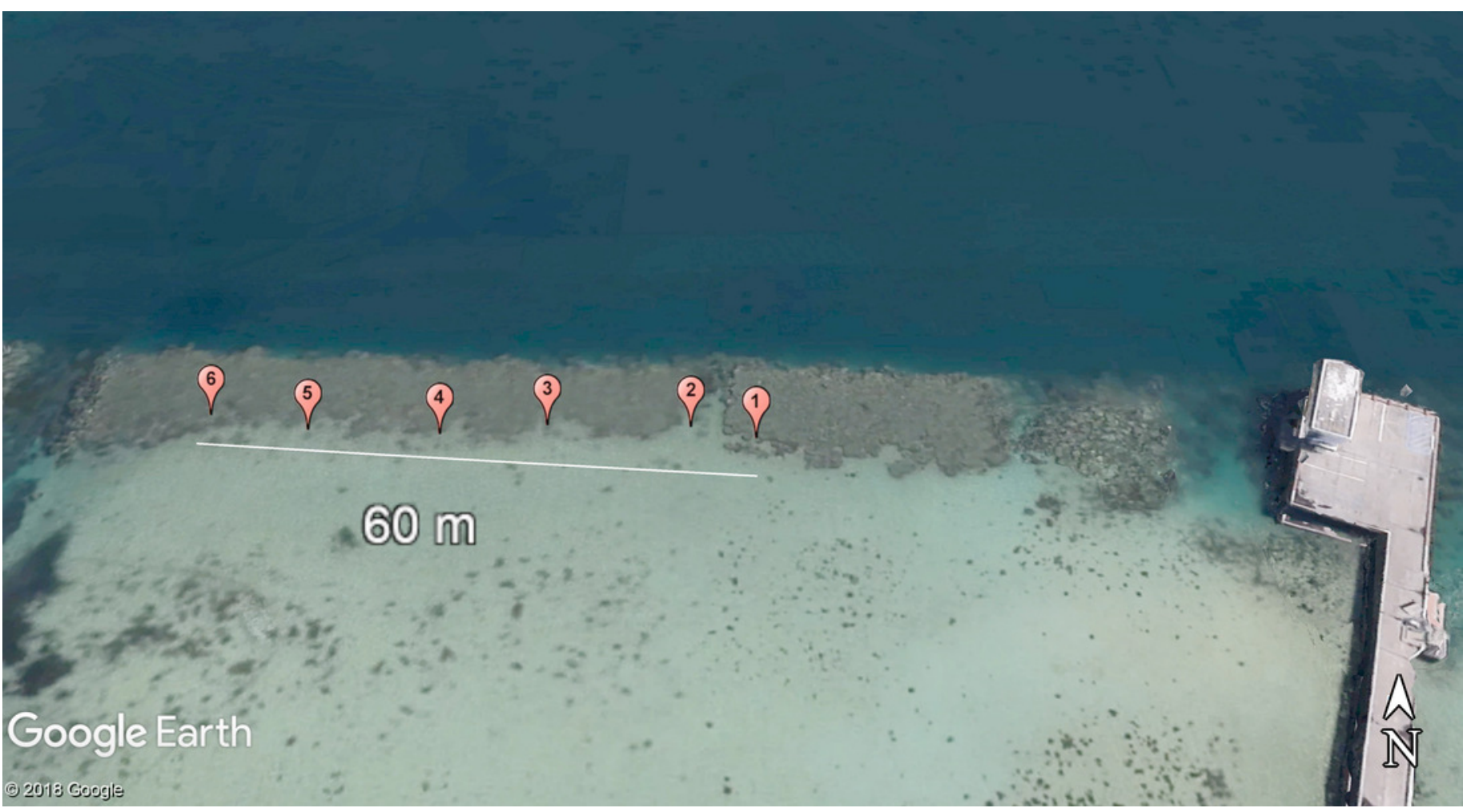




\section{Figure 2}

Antioxidant enzyme activity versus moon phase cycle.

(A) CAT activity characterized by the consumption of $\mathrm{H}_{2} \mathrm{O}_{2} \mathrm{mmol} / \mathrm{min} / \mathrm{mg}$ protein, (B) $\mathrm{GR}$ activity characterized by the consumption of NADPH nmol/min/mg protein, (C) Seindependent GPx activity characterized by the consumption of $\mathrm{CHP} \mathrm{nmol} / \mathrm{min} / \mathrm{mg}$ protein, (D) Se-dependent GPx activity characterized by the consumption of $\mathrm{H}_{2} \mathrm{O}_{2} \mathrm{nmol} / \mathrm{min} / \mathrm{mg}$ protein, and (E) SOD activity characterized by the inhibition of cytochrome c reduction $\mathrm{mmol} / \mathrm{min} / \mathrm{mg}$ protein versus moon phase cycle (planulation peak during $1 / 4$ moon phases)(error bars represent mean $\pm S D$, treatments that share the same letter are not significantly different $p$ $=0.05$ ). 

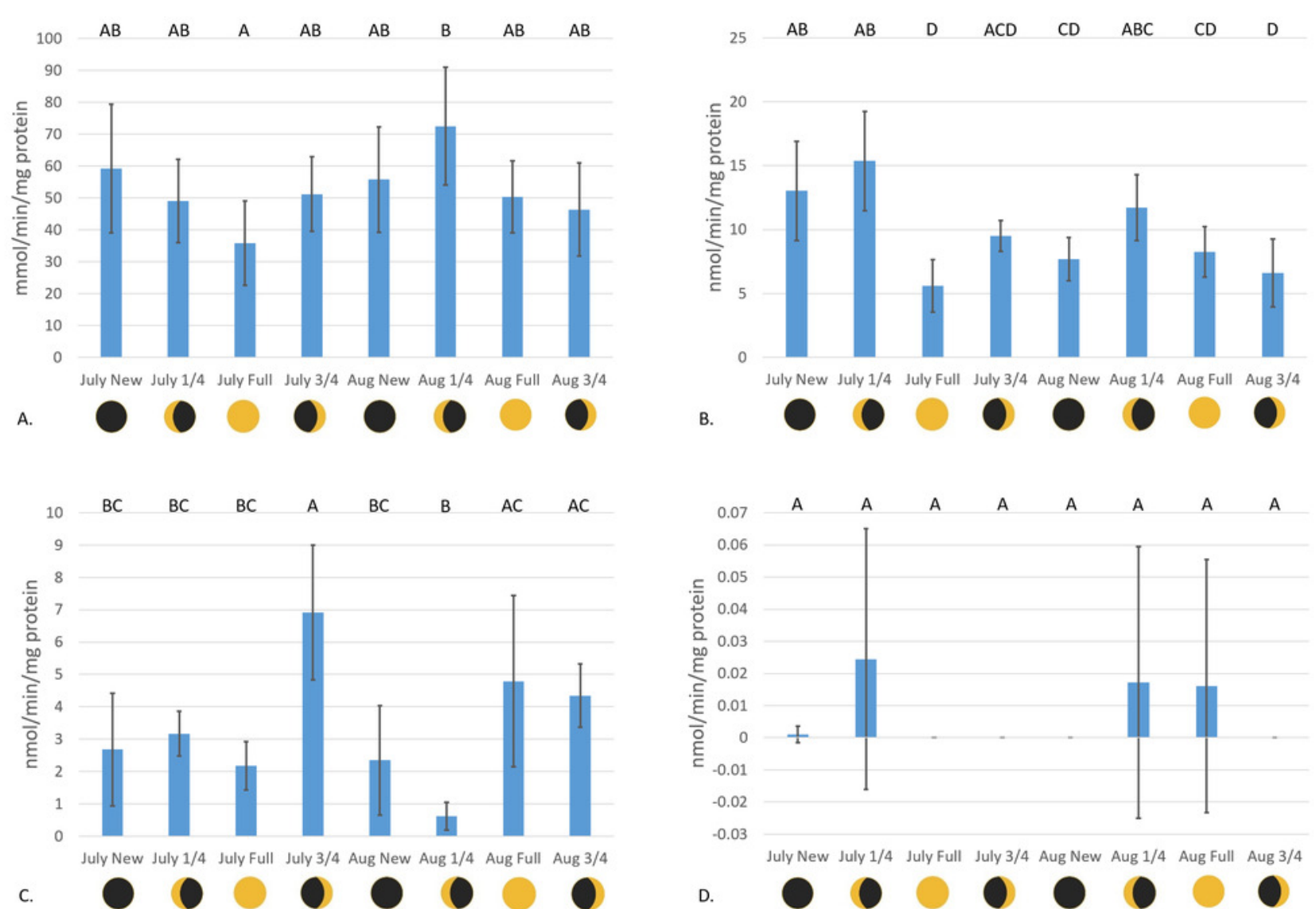

c.

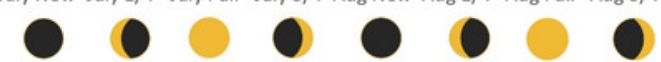

D.

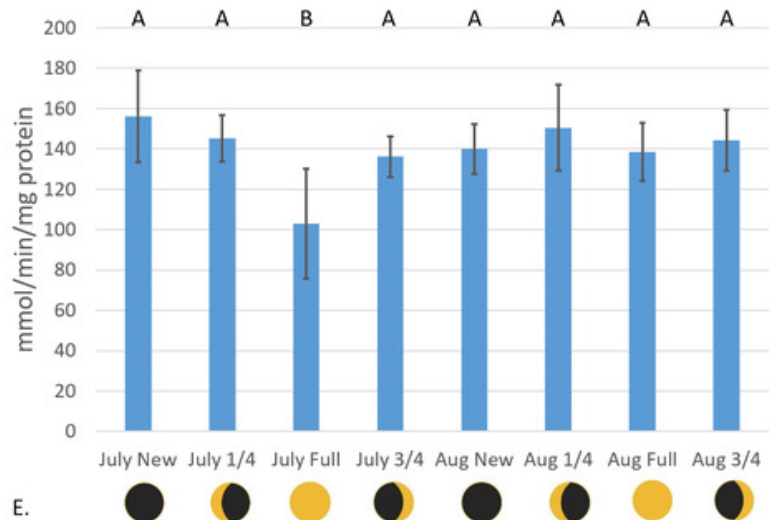




\section{Figure 3}

Antioxidant enzyme activity versus time after peak reproduction (1/4 moon phase).

(A) CAT activity characterized by the consumption of $\mathrm{H}_{2} \mathrm{O}_{2} \mathrm{mmol} / \mathrm{min} / \mathrm{mg}$ protein, (B) $\mathrm{GR}$ activity characterized by the consumption of NADPH nmol/min/mg protein, (C) Seindependent GPx activity characterized by the consumption of $\mathrm{CHP} \mathrm{nmol} / \mathrm{min} / \mathrm{mg}$ protein, (D) Se-dependent GPx activity characterized by the consumption of $\mathrm{H}_{2} \mathrm{O}_{2} \mathrm{nmol} / \mathrm{min} / \mathrm{mg}$ protein, and (E) SOD activity characterized by the inhibition of cytochrome c reduction $\mathrm{mmol} / \mathrm{min} / \mathrm{mg}$ protein versus time following peak reproduction (error bars represent mean $\pm S D$, treatments that share the same letter are not significantly different $p=0.05$ ). 


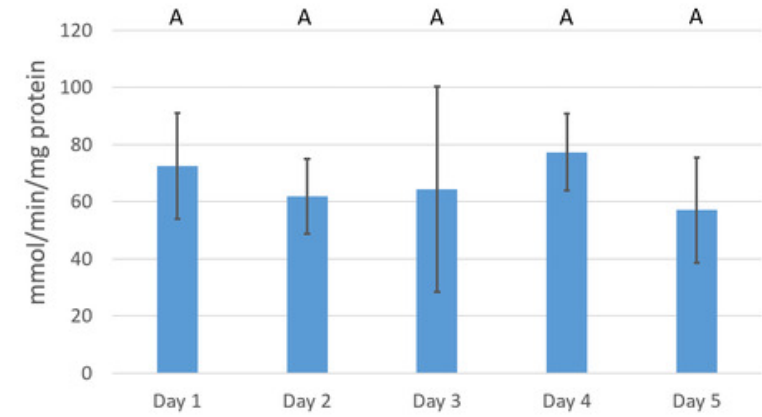

A.

Days following August $1 / 4$ Moon Peak Planulation

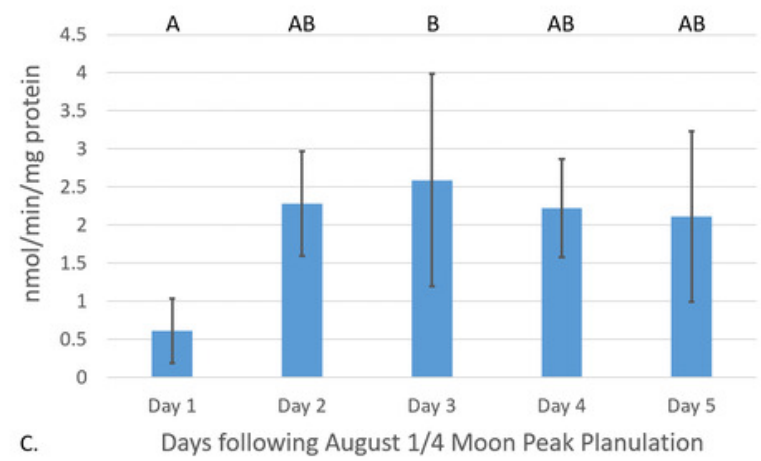

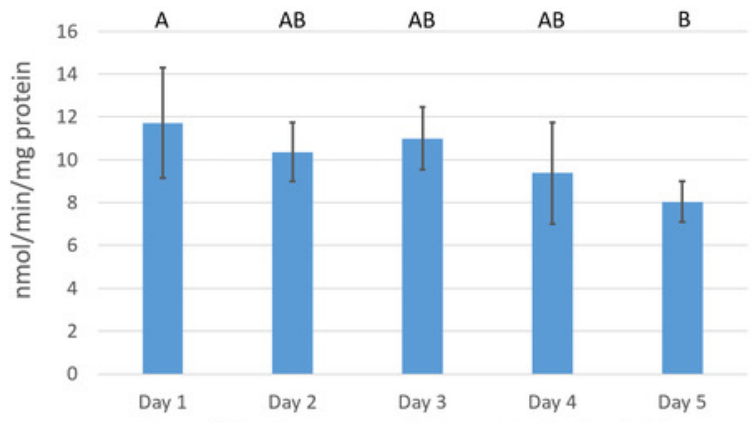

B.
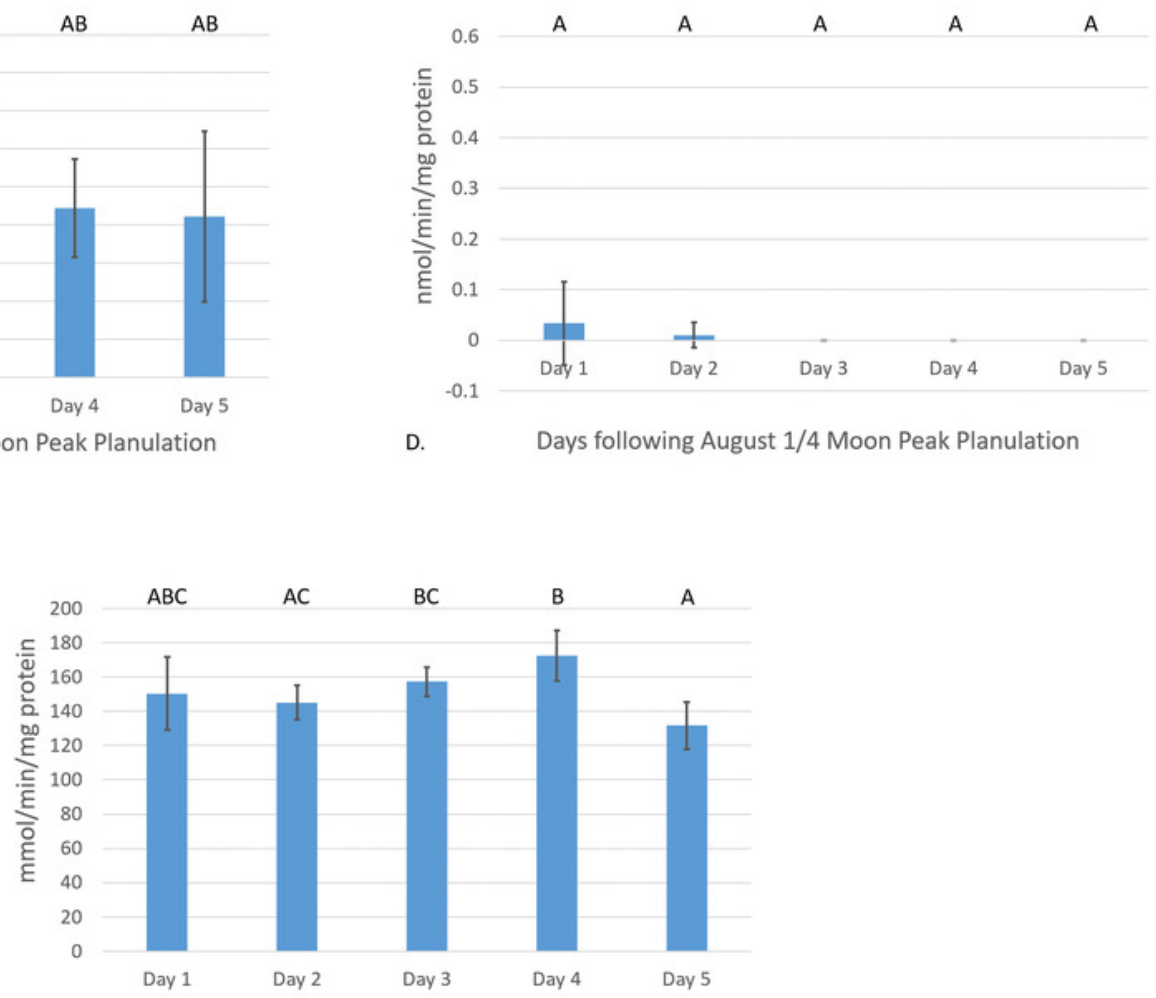

E. Days following August 1/4 Moon Peak Planulation 